\title{
Articles \\ Keeping public cyberspace open: Lessons from the Pacific Islands
}

\section{ABSSTRACT}

A number of empirical and conceptual lessons can be drawn from a closer look at atypical, non-western uses of the internet. Drawing on a study of two pioneering discussion forums, the Kava Bowl (KB) and the Kamehameha Roundtable (KR), maintained by diasporic Pacific Island communities, this article celebrates the existence of open, accessible cyberspaces in an increasingly privatised internet environment. The day to day operation of the $\mathrm{KB} / \mathrm{KR}$ fora are argued to demonstrate the limitations of classical 'public sphere' thinking. In particular, the way in which power and influence is rendered in these online formations calls for a new conceptualisation of 'public-ness'. Michel de Certeau's concept of 'everyday life' is argued to provide a fertile link between Pacific Island internet practices and broader internet debates. In conclusion, it is argued that the way in which the 'public', the 'private', and 'technology' are construed in Western literatures, leaves non-western internet practices subsumed under ethnocentric and techno-determinist assumptions about the interrelationships between technology, culture and society.

\section{MARIANNE I. FRANKLIN}

University for Humanist Studies, Utrecht

\section{Introduction: Welcome to the Pacific Islands Online}

We use volunteers and nobody is paid to do this. In fact you will find admin are students or fulltime workers who take care of the kavabowl on their own time. Sometimes reading every single message over a slow connection can be quite an effort ... Basically, personal messages can 
be sent by email, messages with Loooong titles will be deleted since they clutter the board. Any offensive messages or anonymous messages which accuse a specific person are deleted. (Taholo Kami/KBAdmin, $\mathrm{KB}, 04 / 02 / 00$, in taeoli, 4/02/00).

Thank you Al and Sue: Chiefs, Good to see the [Kamehameha Roundtable] Forum back up. All the best to you two. (Meilakepa, KR, $20 / 03 / 05)^{1}$

$\mathrm{D}$ ISCUSSION forums, newsgroups, live chat and other sorts of everyday online conversations tend to be regarded as a lower order of internet-based communications in debates about the impacts of information and Communications Technologies (ICTs) on contemporary politics and society. Text-based interactions that occur 'naturally' (Sharf, 1999) in countless websites on the World-Wide Web are passed over as banal; sorts of onlineness that are incidental to more pressing issues about the digital divide (Mansell and Wehn, 1998, OECD, 2001), cyber-terrorism, ICTs and democratisation, $\mathrm{R} \& \mathrm{D}$ policies for the world information society and such like. When they do attract attention, assessments of their sociocultural, or political worth tend to be less than encouraging (McChesney, et al 1998; Schiller, 1999, Wilhelm, 2000; May, 2002).

But, corporate manoeuvrings for control of the glitzy interfaces and gigabyte-sized flows of the present, and future, internet notwithstanding, it is the myriad of daily, text-based and relatively low-capacity communications that still form the bulk of Internet traffic. Dependent upon these less glamorous applications are at least two generations of internet-based communitybased exchanges (Ludlow, 1996; Shields, 1996; Jordan 1999). These are social interactions that occur and accumulate within, what I shall call open public - cyberspace. Cyberspace denotes where a person is, or goes, figuratively speaking, during online (inter)actions. Actions that are delimited and facilitated by the functional parameters of the World Wide Web's browser and hyperlinking software (physical access and compatibility issues being taken as equal for now). By public cyberspace, broadly speaking, I mean websites that are premised on non-exclusive, not-for-profit access, once online (intergovernmental or non-governmental organisations, university websites). Further to these sorts of standard 'open access' cyberspace are those that go together with lateral (peer-to-peer) sorts of interactive, intertextual commu- 


\section{THE INDIGENOUS PUBLIC SPHERE}

nicating (newsgroups, live chat, bulletin boards) and, more particularly, those with online conversations that are horizontal, multi-directional and cumulative. The regular maintenance of cyberspaces such as these is down to voluntary labour (Taholo Kami, op cit); their satisfactory operation for their constituencies dependent on varying degrees of (negotiated and acceptable) moderation (Meilakepa, op cit). Hence they differ in important respects to the broadcasting model (one to many) of the aforementioned (inter-)governmental and commercial spaces on the Web (United Nations and Microsoft websites respectively). Their viability as living, populated and accessible online meeting-places in the longer term are ascertainable in the longer term (years as opposed to weeks or months). The degree and porosity of the connection online public forums have with on-the-ground (offline) domains underscore their inclusive, open-ended characteristics, rather than their assumed antisocial, hermetic tendencies.

This article celebrates the existence and persistence of these forms of online 'public-ness'; however tenuous their futures may be in the increasingly commercialised and cordoned-off spaces of the internet. It does so by drawing on a study of two major discussion forums maintained by and for Pacific Island communities from Tonga, Western and American Samoa (albeit not exclusively); portals that date from the earliest days of the WorldWide Web. ${ }^{2}$ These are cyberspaces that have been set up, populated and sustained for nearly a decade by, and for Pacific Islanders living overseas; in New Zealand, Australia and the USA for the most part but, again, not necessarily. More than a few participate from the islands too. As online practices in their own right, these intercultural and intracultural (re)articulations of everyday life for postcolonial and diasporic Pacific Island communities are also translocal in form and substance. In both these respects, the Pacific Forum's Kava Bowl and the Polynesian Cafe's Kamehameha Roundtable discussion forums show up the cultural and conceptual limits of 'public sphere' thinking in itself. A close look at the daily operations, content and populace of these pioneering 'PI' sites, and their many spin-offs, indicate how ICTs can be community facilitators for indigenous peoples, ethnic minorities, disenfranchised groups and successive generations of postcolonial diasporas if applied and adapted for these communities' actual, as opposed to presumed needs.

In the first part of the article, I introduce these particular 'public cyberspaces': a brief look at their history, some samples of two interlocking 
clusters of discussion themes (Franklin, 2004; pp.75-136), and how power relations are rendered and exercised in these sorts of onlineness (ibid., pp.168195). These Pacific traversals offer another tale of the internet: as a generically public medium (arguably and not without difficulties) that is under pressure from surveillance and hyper-commercial forces. As online practices and public records these forums articulate a nascent postcolonial politics of representation (ibid., p. 14-16), as they are lived or perceived by participants, in the islands or situated as 'minority' communities elsewhere. The second part reflects upon some implications these traversals in public cyberspace have for further work on how any 'public' cyberspace comes about, and for whom. For there are persistent conceptual problems with how the 'public' and (internet) 'technology' are still construed in predominantly Western literatures where empirical lacunae - postcolonial, diasporic, or indigenous applications and experiences of ICTs - are subsumed under ethnocentric and technoeconomically determinist assumptions (Kolko et al, 2000; Wyatt et al, 2002). There are also some specific lessons about how to analyse, indeed locate public-ness in internet-mediated societies that can be drawn from non-western internet practices in open cyberspace. These Pacific (cyber)spatial practices of everyday life are exemplary. In the last part of these reflections I touch on Michel de Certeau's conceptualisation of everyday life and its pertinence to PI travels online and on-the-ground. The political point of his 'practice theory' is that empowering spaces, forms of public-ness, emerge by being practised and inhabited, rather than imposed and enclosed (see Franklin, 2001; 2004, p. 48 passim).

\section{Everyday life in postcolonial cyberspaces}

Is it not better for Taholo and other Tongans to be putting forward knowledge of their own culture than for an outside interpretation of that knowledge by others to be considered the norm. It has to be remembered that before Tonga Online ${ }^{3}$ there were no other sources for information on Tonga on the internet outside of the sites developed by overseas institutions and individuals and the rather trashy tourism pages around... By allowing discussions on his pages Taholo is showing an independence of thought which he needn't have done. The internet's value is in its ability to allow interaction by users, as opposed to one way bombardment of information ... by allowing freedom of expression (to an extent - where expression is not harming others), Taholo is encouraging debate on the Pacific and a site where Pacific Islanders can communicate 
THE INDIGENOUS PUBLIC SPHERE

with each other from all around the world. The Polynesian Cafe [Polycafe] is not a competitor, but rather a tribute to Taholo's ingenuity ... ('Alopi Latukefu, KB, 23/09/96 )

In 1996 I created [the Kamehameha Roundtable Discussion Forum] for Polycafe patrons (regardless of race) to come together and discuss 'just' the issues that affect us as individuals knowing such an effect will certainly impact the 'community'. Some of you may recall how I would initiate new discussions every week, posting 4-5 new topics once a week. That lasted for several months before the forum itself took on a life of its own as it CONTINUES TO DO SO TODAY .... (Al Aiono, 13/ 01/00 in concerned, KR 13/01/00)

The internet forums examined here stem from the Kava Bowl Discussion Forum (1995-2001) of the pioneering Pacific Forum (http:// pacificforum.com). The Pacific Forum was set up in the mid-1990's by Taholo Kami. The Kava Bowl (KB) rapidly took off, emerging as a significant debating forum for Tongans, in the islands and abroad, which attracted popular and academic attention (WIRED, 1998a, b; Morton, 1999; Ogden, 1999; Franklin, 2001, 2003). One of the first spin-offs was the Polynesian Café, run by Al and Sue Aiono out of Los Angeles, USA. Its Kamehameha Roundtable/ Polycafe Discussion Forums (KR/Polycafe) (http://polycafe.com/ kamehameha/kamehameha.htm) also became a recognisable focal point for Samoan participants and topics. In practice, Tongan, Hawaiian, Maori New Zealand and other Pacific Island participants regularly commuted between the KB and KR from the outset; non-exclusiveness and hospitality being an important part of their founders' communicative ethos and website design ('Alopi Latukefu, op cit, Aiono, op cit). There are participatory, stylistic and thematic distinctions between the Kava Bowl and Kamehameha Roundtable (see Franklin 2004, p. 196 passim) but these need not be overly emphasised. Mainly because the two forums have not only been hyperlinked to one another, but participants also maintain multiple participation; literally and figuratively. $\mathrm{KB}$ regulars who moved over to the $\mathrm{KR}$ when the $\mathrm{KB}$ went offline in 2001 effectively merged what had always been two closely linked spaces. In any case, many Kava Bowl 'old-timers' have participated regularly on the Kamehameha Roundtable from the early days, including members of the original KB Administration (KBAdmin). ${ }^{4}$ The Kava Bowl has since been replaced 
THE INDIGENOUS PUBLIC SPHERE

by the numerous forums on Planet Tonga (http://planet-tonga.com/forums/) for specifically Tongan / Tongan diasporas. ${ }^{5}$ The Pacific Forum and Polycafe have been the backbone of the Pacific Islands Online since the 1990s; their website design and communicative styles adopted by other Pacific Island websites in their wake (Lee, 2003). These PI/Poly cyberspaces are striking by their participatory longevity and consistency in the first instance; the wealth and vibrancy of their accumulated textual production over the years in the second. Their user-interfaces, online traffic and, more particularly, their textual content constitute cumulative online archives of everyday life. Archives are created in toto by all those who 'post' an initial message or follow-up. All are welcome to participate, albeit according to the forums' posting policies and more implicit codes of conduct. These are (gently, but clearly) moderated and consensual public cyberspaces. Discussion themes, whether new, recurring or evolving, cover issues pertaining to both specific countries, overseas communities or the Pacific Island region as a whole; ranging from the impact of (neoliberal) globalisation imperatives, to Tongan political unrest, to individual 'identity crises', local and global politics, cultural and racial stereotyping and community accountability for socio-economic (under)achievement (see McNichols, Humphries and Gallhofer, 2003).

The years 1997-2001 were the peak for both forums, as they were for the web at large; a period where constituencies consolidated, interpersonal and power dynamics, thematic nodes crystallised. By all accounts, the age-range of participants is from 17 to 50 plus years of age; grandparents, parents of young children, university and high-school students, housewives. When not school students (often discernable by both topic and idiom), participants tend to be in their twenties or thirties (Aiono, 1999, interview; Kami, 2001, interview). Many participants, in the Tongan-based Kava Bowl in particular, position themselves as practising Christians or as socially 'conservative'. There is a fairly equal spread of men and women participating, both by name, implicit and explicit identification through discussion threads' manifest content (Franklin 2001, Morton 2001). ${ }^{6}$ The first and second generations of the mid20th century migrations of Pacific Islanders to New Zealand, Australia and the USA are the most active. When interacting with those posting directly from the Tonga, Samoa, Fiji, Hawaii, or elsewhere, there can be sharp disagreements. Where someone is posting from becomes manifest at these moments, and also points to other (socio-economic, psycho-emotional) sub-texts 
in play. ${ }^{7}$ For instance, this more recent initial post recalls a recurring theme:

My husband and I are first generation Samoan-Americans born and raised in California. We would like to influence our children to learn more about their Samoan heritage. The question they had was, why? Ironically, it made me and my husband wonder why it was important. We are both happy being American. We enjoy the American culture which is really the only culture we know. However, somehow, are relatives and fellow Samoans tend to guilt us into feeling as though we were blatantly denying a heritage that would enrich our American culture. Knowing this, I was hoping the wise here could possibly provide a list of traditions and/or cus-toms [sic] that our second generation American children could or should embrace and why they are valuable to their futures. I look forward to the information. (Mr.Mrs first generation lost, KR, 31/12/04)

People keep coming back to these forums (and attest to this) because these are places in which they can deal with issues that matter for them, in their everyday life, whether in the islands or 'when living overseas' (KBAdmin, $\mathrm{KB}, 16 / 11 / 98)$. Whilst these sites are 'owned' by their individual founders, who are legally liable for online content and also take their role (and are seen) as online community leaders quite seriously, these forums are largely selfregulating. They are open, transparent in that they are accessible, content is readily available and, more or less, writers are aware that even their most personal interactions are effectively available to one and all. Some of the tougher and more recurring debates pivot on the interlocking of the interpersonal and the world-wide dimension. Before we take a closer look, it bears mentioning that whilst these forums were set up for 'serious' discussion, there is nonetheless a lot of humour, satire, and (self-)parody in even the more intense debates. For instance, in the midst of wrangles about the politics of correct, or incorrect, language and demeanour on these forums, one wit posted the following rejoinder:

I personally love using profanities. The language of the sewer delights me. The first stream of daily profanities erupts from my lips at $6.30 \mathrm{am}$ when, at the screech of the alarm clock, I tumble unceremoniously onto the icy cement floor...The second stream of profanities ignites when I can't 'do my job' easily on the bathroom throne. The third ricochets 
around the tiny bathroom when the razor cuts my chin during shaving ..... BUT upon exiting my cockroach-friendly apartment, I forget all about freedom of speech, and behave with relative decorum and respect for the sensitivity of others.... Most respectfully yours-in-the-faithin-freedom-of-speech. (Ki'i Sulu, KB, 26/04/99 in Lafemme Nikita, 23/04/99)

Individual interventions and whole threads can be as polemical as they are reflective, as carefully argued as they are emotionally charged, intimate as well as declamatory or written for a wider audience; with intracultural and intercultural dimensions. The blurring of personal (intimate) and public (societal) relationships are most palpable in two clusters of interwoven themes: sex-gender roles and identity-formation along 'race' and cultural lines.

\section{'Neoclassic Samoan woman', 'libby women', 'woman and Samoan'}

In a series of overlapping exchanges in the $\mathrm{KB}$ and $\mathrm{KR}$ about the nature and exigencies of 'traditional' and 'modern' sex-gender roles (Rubin, 1997, p. 28) for Samoan and Tongan women, female and male interlocutors talk openly about the stresses and strains of intimate and familial obligations bound up in 'being a woman today' in the islands, and abroad. What is at stake in these threads are contested meanings about sex, gender and culture for so-called traditional or modern Pacific Island societies. The benefits of living overseas do not mean for many women participants either an automatic improvement in women's socio-economic situation as a whole or a release from a range of familial, cultural expectations of their own 'woman's role'. Two examples illustrate the cross-cutting affiliations, intercultural positionings, at stake here:

I was much disturbed when reading your posting because you made Tonga out to be some sort of cesspool for gender discrimination, when in fact, there are more women working in the civil service in the Kingdom than here in New Zealand, also out in the villages, a lot of women provide the backbone for much of the families - and I can assure you their roles ... are not those of a docile domestic worker, but rather of a strong nurturing and dignified female figure, some of which simultaneously hold jobs! ... Tradition is not a hindrance - but rather something I very highly esteem. Our 'fahu' system is unique and esteems the woman as the most important member of the family - not even the glorious western world has such a provision. And merely because individualism 


\section{THE INDIGENOUS PUBLIC SPHERE}

is highly prized in the rest of the world, does not mean that we should automatically adopt it - please do not be resigned to making Tonga into another semi-Western clone!... (Legacy_NZ, KB, 20/05/99 in Lausii, 18/05/99).

I'm a young woman and growing up in a new generation...... I find my peers (the 30 something crowd and up) have it a lot easier than did our mothers before us. It is our mothers who truly were under-represented, barely vocal and hardly seen... I have not heard anything in my upbringing COMMANDING that relationships be dichotomised....Woman and Samoan ... and quite capable of carrying both. (..., KB, 20/05/99 in Lafemme Nikita, 19/05/99)

Another set of queries, contestations and affirmations can come flying in response to (male) participants' assertions about the nature and desirability of 'traditional' sex-gender roles for Samoan or Tongan women in particular. Whether posted tongue-in-cheek or not, irate or bemused responses from women are quick to follow. For instance, in a thread entitled Where are the Caring Women?, (KZ7, KR, 28/03/00), came these follow-ups :

In many societies including Polynesians, an IDEOLOGY of motherhood pervades all levels of society, claiming the adherence of women from all walks of life and socio-economic backgrounds. I believe that the ideologies of motherhood and femininity are closely enmeshed so that a woman's sense of femininity is entwined with the potential or actuality of motherhood (Venus, The Aphrodite, KR, 28/03/00 in KZ7 28/03/ $00)$.

What a load of crap ...... As far as I'm concerned, and I proudly speak as a feminist, not enough has happened. The women's movement has moved backwards with young women being lulled into the belief that they have achieved everything..... Go through what women have asked for in the women's movement, and you'll see that very little has been achieved. And if you aren't a male, then it really does prove that women have been duped (NINJA, KR, 28/03/00 in KZ7 28/03/00).

Do you mean to imply that women who are not full-time homemakers are less caring? If so, then I take exception to that very strongly. Yes, I work- full time. And yes, I have to put my son in the hands of strangers 
while I work. But I can assure you, that makes me no less devoted to my son than any stay-at-home mom (Teuila, KR, 28/03/00 in KZ7 28/ $03 / 00)$

Defining what it means to be 'a Samoan [or Tongan] woman today' splices through other threads that debate contested meanings and experiences of 'ethnicity', 'race', and 'culture'; postcolonial / diasporic 'identity' in short.

\section{Everyday embodiments, cultural codes, empowering futures}

The threads probably comprising the bulk of discussions, intimately linked to those above on sex-gender roles, sexuality, religion and morality, are from those living as US, Australian or New Zealand citizens and yet finding themselves 'caught between identities' (Kami, 2001, interview). Experiences of discrimination are shared along with ideas about how to transcend - or confront - prejudices based on being racially - ethnically - 'marked'. Whether posting messages from Nuku'alofa, Apia, Los Angeles or Salt Lake City, Auckland, Sydney or Melbourne, at the heart of these threads, and woven through many others, are the outer and inner limits of an 'identity' as a carrier of (multiple) meaning for people living within, and between multiple ethniccultural locales and expectations. The various cultural practices put under the magnifying glass here are Fa'a Samoa (the 'Samoan Way') and anga fakatonga (the 'Tongan Way'). Moreover, what do Fa'a Samoa and anga fakatonga entail for those who have several cultural - 'racial' - heritages? Debates can begin, and end, with arguments about the 'essential' features of being Tongan or Samoan, whether similarities outweigh (perceived) differences, whether cultural 'destiny' is down to racial 'purity' vis-à-vis the ambiguity of 'mixed blood' ${ }^{8}$ Experiences of racial discrimination by society at large are accompanied by accounts of comparable forms of exclusion from within Pacific Island communities. Cross-cutting these reflections are claims about the need to concentrate on the mutual interests and ties that bind various Polynesian/ Pacific Island communities in urban centres where gang violence, endemic under/unemployment and dearth of educational opportunities are indicators of socio-economic and ethnically-labelled forms of stigmatisation and polarisation, within and between communities. Over the years, many threads have been woven on concerns such as this one:

This is in response to everyone who went and research things not only 
THE INDIGENOUS PUBLIC SPHERE

for myself but also for others to pass on. .... My point is that we Polynesians ARE connected and should be proud that we are, its just that most people tend to get confused as to what the differences are between a Hawaiian or Tongan or Samoan. .... We come from beautiful and wonderful cultures and it will be refreshing one day when my fiancée doesn't have to explain over and over what a Tongan is. She is TonganTahitian-French. She is very proud of her Tongan side AND her Tahitian side and would also love it if others were a little more educated since we could all use some education from time to time. We both appreciate it very much, since there will be much to teach our kids :). (Concerned Hawaiian, KR, 31/01/01 in From a Concerned Hawaiian, 29/01/01)

Participants confront here a range of conceptual ambiguities, politicised essentialisms, and community-level parochialisms. Whilst the terms 'race/ culture/ethnicity' (Lillian, KB, 17/09/98 in KBAdmin 14/09/98) are treated as mobile meanings in themselves, people wonder out loud about where and how they also operate as forms of closure, confinement. Policies of positive discrimination are particularly poignant focal points for this 'double function' of racialised-ethnic and gendered boundaries (Borradori 2003: 145). Two participants in a thread entitled Any Future US Political Clout for PI's?? (eb, KR, 12/03/01) are well aware of the limits of possibility here, in theory and practice:

The point is we shouldn't demand representation based on skin color. That is racist because inherent in that thinking is that ALL people of a particular race have the same needs and the same way of thinking on issues. It is not true. You can't bundle us up according to skin color. We spent two hundred and some years getting away from that mindset. (Bevo, KR, 14/03/01 in eb 12/03/01)

I wish I did live in a color blind society, but I do not. People still hire people that look like them. (Sinafea, KR, 14/03/01 in reply to above)

Participants describe themselves, their siblings and their children by their (various degrees of) skin, eye and hair colour, said culture and lineage/ancestry and dual or singular nationalities. Specific personal conundrums for participants with mixed parentage pivot around questions such as where envi- 
ronment and upbringing diverge or converge with 'natural' or cultural traits. Physical features aside, how dynamic are Tongan or Samoan cultural practices anyway let alone when they are practised elsewhere, or are part of being married to, having children with someone from the Pacific Islands? What do - or should - terms such as Polynesian, Pacific Islander mean for contemporary times, diasporic lives (MVP, KB, 13/11/99; Thoughts, KR, 22/05/99, TonganRasta, KR, 6/06/01)? Here, the viewpoints of US-based participants (the majority in the KR at least) often get pitted against those of Tongans and Samoans living in Australia or New Zealand. Those participating from the Pacific Islands themselves make clear where they agree or disagree with all of the above.

But these threads tackle troubling intracultural and (extended) familial tensions as well. Queries from participants who talk about the pressure of not fitting the requisite physical stereotypes, or from those who cannot perform the cultural rituals, speak the language of their nominal culture, or mix of cultures are addressed; with painstaking tenderness at times and less tolerantly at others. At the same time, younger participants claim the right not to be confined to the cultural expectations of their parents or community norms. In any case, the general tone is one of exploration and inquisitiveness about what is seen as a life-long process:

Being Tongan means a unique starting point on a long journey to be a better human being - having learnt that there are admirable qualities in other humans on this planet which can be embraced...... Being Tongan is to accept that life is chaos to be enjoyed. (Sefita, Auckland, New Zealand, 12/03/98 in KBAdmin 9/03/98)

At the heart of these ongoing discussions are more elastic, dynamic understandings of 'race', 'ethnicity', and 'culture'. In this sense, identity operates as a trope for 'becoming'; a lifelong journey, undertaken on one's own terms in negotiation with a host of others. All in all these sorts of threads are upbeat rather than gloomy in tone; infectious and idealistic interventions rather than those made by 'hataz' (haters). Developing reasons for nurturing solidarity and support networks within and between various island cultures are key motivations for many participants. Whether these conversations can be put down to youthful idealism or not, these threads put to task the doomsday prophets who would see 'race' or 'ethnic' identity politics as necessarily divi- 
sive even when community tensions are all too evident in offline situations. The goal - ideal - is one of unity and community; where future visions have to be worked at. For one way to counter inter/intracultural prejudices on the ground is to talk them through.

\section{Moral economies}

Most of the reason people come in this cafe is to read the drama. Its entertainment, and whether you like it or not, it brings people in here...One question I have is about your thoughts on slang. I don't see anything wrong with it. A lot of our people grew up like that, why would you wanna bann something like that. But like u said, it's your house and your rules... (Keepin it real, in POLYCAFE 4/05/99)

The Kava Bowl and the Kamehameha Roundtable are frequented by living, writing, reading inhabitants (whatever their 'nics' or 'handles') who co-create the formal and substantive contours of these forums as they go. Various sorts of (in)formal power and influence can be seen at work here. The effectiveness of these forums over time is also due to the lengths moderators go to ensure that they remain welcoming, providing room for disagreement but not carte-blanche. While characterised by their spontaneous, forthright and lively nature, the sheer volume of traffic, between 1998-2001 especially, required in 2000-2001 some thinking out loud about the direction of the forums and their raison d'être; themes reiterated since. A closer look has shown that what are couched as technical-legal concerns are spliced with behavioural and ethical considerations of their own. I call these moral economies because they are not about just 'housekeeping' issues. They entail the ongoing (re)negotiation of propriety codes (language-behaviour) vis-à-vis the very gendered and cultural codes discussed in other threads (see above). Nascent moral economies revolve to a large degree 'around questions of ethics' (Kolko et al, 2000, p. 2; Franklin, 2004; pp.13-16, 168, passim). The ethical imperative referred to here, and certainly in moments of direct altercations, is the KEYWORD HERE: RESPECT - For self, for others, and for the general spirit of this forum" (../Anni, KR, 23/11/99 in Daily Planet 21/11/99).

While the technical means to enforce the ground-rules reside with individual or co-moderators, neither their role nor their room for enforcement go uncontested. There are four axes around which these moral economies can be seen at work over time. The first axis is for those threads in which leaderships 
declare their intentions to delete a post and/or reiterate the rules. This often merges into the second axis: when leaderships and their rule-making are directly challenged, queried, or applauded by their constituencies. The third is constituted by 'personal attacks' or 'flames'. The fourth axis is an amalgam of more self-conscious posts about representation/image-making in light of all three of the above, sometimes instigated by the leadership and sometimes by concerned participants. These axes are, in turn, linked to four 'fundamental principles' that are at stake for participants at some time or other: Free Speech, Ground-Rules, Respect, Legitimacy.

First, the notion of 'free speech'. As with on-the-ground wrangles about the ethical and practical limits to this quintessential right in democratic societies (from the Netherlands, to the US, to Tonga), the exercising of Free Speech by KB/KR participants has run head-on into the both moderators' and fellow participants' limits in allowing unmitigated self-expression; let alone the legal liability increasingly carried by website - content - 'owners'. Any direct action taken in this respect (and the ensuing arguments about them) is justified by the Ground Rules criterion. These first two criteria are then connected to a more amorphous but no less palpable principle for these forums; the aforementioned notion of Respect. ${ }^{9}$ These online renditions of 'power over' and 'covert power' (Gill \& Law, 1988, p. 73; Kolko et al, 2000, p. 4; Toulouse and Luke, 1998) and influence online are coupled to the fourth criterion, legitimacy. It is when a moderator's authority or a participant's ability to resist enforcement - or persist - is at stake that the legitimacy criterion comes to the fore. This more confrontational moment ('personal attacks' which contravene the KB and KR ground-rules for happy participation) can range from asking someone the 'who are you?' question, various degrees of angry retorts, personal insults, showing annoyance LOUDLY (capital letters can used for emphasis but tend to come across as online shouting) or repeatedly; or withdrawing altogether. It is here that two other factors are in play: what constitutes 'profanity' or 'slang' (Ki'i Sulu, op. cit.)and issues around anonymity. The latter aspect, often the focus of scepticism about the inherent value of online communications, works in particular ways in - and for - the open-ness of these conversations (see Morton, 2001; Franklin, 2004, pp. 185 186). These principles and their bearing on rectifying negative stereotypes are both source and focus for discussion. For instance:

A few months ago, I posted a discussion thread about being tired of 


\section{THE INDIGENOUS PUBLIC SPHERE}

hearing Polynesians talk slang and what type of image or impression it gave to others....I am very happy to see that the Polycafe has raised their standards ....This is only going to help in destroying the stereotypes that have been bestowed upon our people. I would like to see that our people are known more for just being big people who can kick ass... If I want to read or listen to slang or profanity, I can go down to the parks and look at the graffiti for that garbage. Thank you for ridding this website of all the riffraff and all the gangsters...(Sam Owens, Polycafe, 20/05/99)

Sam ... doing away with profanity was a great move. But I have to say that I ride the fence on the slangs being cut as well. ... on days when I feel like relaxing a bit with my words and corresponding in this public forum with friends and family, opting to use some slang, or even made up words of our own, mostly just for fun.... maybe I see things differently ...I don't care for the whole misspelled words, tough guy attitude, 'Slang' crap either, but the posts which are by far the more offensive ones are ... the ones that are posted to purposely be hurtful...... Much gratitude to the Café's administration for cracking down. I am a Polynesian woman who is versed very well, in both verbal and written concourse, but you will catch me on days where I am sending shout outs, what's up etc.. to friends and families. I feel they are harmless forms of communication and hold ho hurtful meanings such as profanity does. ( Lisa, Polycafe, 21/05/99, in Sam Owens, op. cit.)

As these interventions illustrate, online spaces cannot come to life, have no substance, until they are traversed, in this case written and read by participants. On frequenting internet cafes, faikavas, or fales, an online community becomes self-referential and sustainable over time. Changes in their immediate online environments and constituencies. as well as in the internet's physical and digital architectures down the line, so to speak, also impose various sorts of (in)direct pressures on the viability of these cyberspaces/places online. Websites such as these can go offline for 'technical reasons' (pressures exerted by on-the-ground community leaderships being one), as key figures move on to other things, or even die (as in the case of the late Sandy Macintosh - a palangi mainstay of the KB and then KR), or as low-cost technical options diminish, the time and personal input of key participants become too much. In short, neither the appearance nor the continuation of open forums on the Web are technologically or culturally (pre)determined per se.

74 PACIFIC JOURNALISM REVIEW 11 (1) 2005 


\section{Reflections}

\section{The global political economy, the internet and real life}

To all intents and purposes, Douglas Kellner's prognosis that 'information and entertainment material will be thoroughly commodified, available only to those who can afford to pay. ... For computers, like broadcasting, can be used for or against democracy' (1998, pp. 179-180), made in the heyday of the World Wide Web (the 1990's), has proved all too accurate a decade later. The direction that the early 21 st century internet is taking (corporate consolidation of hardware-software ownership and control, intensification of commercial content and tagging as the 'wild west' of web hyperlinking and informational functionalities is tamed and tailor-made for the 'consumer') indicate the colonisation of these, once 'decommodified spaces in the ultracommodified world of techno-capitalism' (Kellner, 1998, p. 182; Schiller, 1999). Deeply nestled in 21 st century Anglo-American-European cyber-angst in the wake of the Millennium Bug scare, computer viruses and cyber-terrorist alerts since ' $9 / 11$ ' are widespread reservations about whether the internet can provide a 'new public sphere' anyway (Kellner, 1998; Loader, 1998; Wilhelm, 2000; May, 2002). Being online is a virtual - unreal - state while political, social worlds offline are real - more true to life.

Less obvious in this literature's reproduction of the classical hierarchical split between mind and body, symbolic and material, virtual and real, is how community-formation, social and political mobilization, games and fantasies on the web have never precluded 'reality' as such, or concrete power relations along 'race', ethnicity, sex/gender, class, socio-economic lines (Kolko, Nakamura and Rodman 2000, p. 4; Henwood, Hughes et al 2001). Cyberspatial practices are no more gender-neutral, classless or 'colour-blind' (Teuila, KR, 26/11/00, in $\sim$ ALOJAH , 25/11/00) than anywhere else. They are, however, configured and rendered differently online. That said, it bears reiterating that the archetypical internet user - and corporate R\&D employee and target customer - is still mainly white, tertiary-educated, middle-income; still predominantly male (even with increasing numbers of female users). Moreover, as more people access the internet from the privacy of their own homes, in internet-embedded parts of the world at least, the 'digital divide' is superimposed over more familiar ones between global 'north' and 'south' (OECD, 2001; Mansell and Wehn, 1998). The existence of 'atypical' users and websites, the online production of their respective constituencies, are only just getting serious attention, despite a number of these being among the first sorts of 
coherent internet-based communities (Dyrkton, 1996, Morton, 1999; Miller and Slater, 2000). The internet/World Wide Web, like other technologies before them, are socially embedded; designed and developed in particular historical, political-economic conditions. This is where the political and economic contestations around ICTs lie. Their sociocultural (race/ethnicity, sex/ gender, class/status) permutations also. But this is only apparent once the internet is regarded as a 'complex, socio-technical whole system that has both symbolic and practical significance' (Wyatt, Thomas and Terranova, 2002, p. 23).

\section{Whose public sphere?}

The Cafe is here to help us explore our Poly Roots and build unity as a people. Samoan, Tongan...It doesn't matter, we all Bleed Red. We need to build each other up, not dogg each other.... Al, keep cleaning up the graffiti in the Café, this way all the patrons will enjoy the cafe. Alofa. (Fatu, Polycafe, 4/05/99, in POLYCAFE, 4/05/99)

The Pacific Island websites that have fanned out from the Kava Bowl and Polycafe internet portals illustrate the insights and problems of Habermasian theories of the 'public sphere'; in themselves, across cultures, and whether universal or particular notions of citizenship, public-ness can, or should be rendered on or through ICTs. To recall, for Jürgen Habermas, the political and social impoverishment of modern, capitalist societies is due to the steady diminution of the 'political function' of public life and civic spaces. Their communicative and political import have declined as commodification processes work hand-in-glove with technocratic forms of management and control of people's social and personal lives; public-ness (Öffentlichkeit) as the sine qua non of healthy, non-oppressive forms of democratic participation reduced to the manipulations of marketing, public relations, and political spin. The modus operandi for achieving this techno-commercial colonisation of the life-world (Lebenswelt) is the mass media/ media industry, in its role as a techno-cultural medium and mediator of socio-political power. For Habermas, as for his even more pessimistic Frankfurt School predecessors (Adorno, Horkheimer et al.), the

communicative network of a public made up of rationally debating private citizens has collapsed; the public opinion once emergent from it 
has partly decomposed into the informal opinions of private citizens without a public and partly become concentrated into formal opinions of publicistically effective institutions. (Habermas [1989] in Outhwaite 1996: 38, see also in Borradori 2003: 85-172)

It is a moot point whether contemporary ICTs actually underscore this trenchant criticism or, counter-intuitively, non-elite practitioners offer openings not yet considered, overlooked by standard accounts. In this study I have taken the counter-intuitive scenario as an empirical actuality and sociocultural phenomenon by virtue of there being close to a decade of visible and legible Pacific traversals in cyberspace. Whatever one's reservations about the limitations of public sphere theorising, with its hopes for 'civil society' responses to the impositions of neoliberal economic globalisation, Habermas' relentless critique of the invidious positioning of the 'rational' citizen vis-à-vis the pervasive power of commercial and political media interests in every part of daily lives bears more than a passing recognition. $\mathrm{KB}$ and $\mathrm{KR}$ regulars have been expressing these issues in a number of ways (see Sandy Macintosh, KB, 27/03/00). Read between the lines of this follow-up in the early days of the Kava Bowl:

It was here that I made friends from all Races. This is a forum, not a place of business. I know to date that Taholo hasn't charged anything for us to come and sit down to commune with each other. Taholo has led our race into the Future. Who are you? Let the Man, Taholo do his thing, Taholo you need not explain, anyone knowing this knows what great Sacrifices you have made to make this possible. (Percy Asi, KB, 20/09/96, in Cyber-cop, 20/09/96)

\section{Lessons from the Pacific Islands}

The practice of everyday life online and offline

One lesson to be drawn from the foregoing can be brought out by considering Michel de Certeau's conceptualisation of 'the practice of everyday life'. In his rendition of the everyday in his 'practice theory' (Ortner op cit; Highmore, 2002), de Certeau emphasises the inventiveness, the creativity of ordinary people as they go about their daily lives; non-elite cultural productions that are part of the public record even when hidden from view (Highmore, 2002, pp. 145-173, de Certeau, 1984, p. xiii). For de Certeau, 'everydayness' is 


\section{THE INDIGENOUS PUBLIC SPHERE}

comprised of a 'proliferation of stories and heterogeneous operations that make up the patchworks of everyday life' (de Certeau, 1980, p. 20, my translation); patchworks woven through with physical displacements and written, sung, recited articulations that are 'constructed-in-process' by those who enact and express them. As they (re-)emerge over time these habits, patterns and detours can be traced. As Ortner puts it, this approach means 'looking at and listening to real people doing real things in a given historical moment, past or present, and trying to figure out how what they are doing or have done will or will not reconfigure the world they live in' (Ortner, 1996, p. 2). For doing (as a verb) is the focus for attention rather than categorisations (de Certeau, 1984, p. xviii; 1980, p. 20).

\section{Accounts of a journey}

Putting the stress on ordinary people's everyday practices, as ones that emerge from the 'bottom up', does not mean dispensing with a sharp critique of prevailing forms of techno-economic and political power over people's lives and movements (as 'citizens') however. Stronger still, for grasping the substantive and formal features of onlineness in general, and as practised by postcolonial/diasporic practitioners in particular, Michel de Certeau makes a salient analytical and ethical-political distinction. Namely a

distinction between space (espace) and place (lieu) that delimits a field. A place (lieu) .... excludes the possibility of two things being in the same location (place).... A space exists when one takes into consideration vectors of direction, velocities, and time variables. Thus space is composed of intersections of mobile elements. ... In short, space is a practised place. (de Certeau 1984: 117/ 1980: 208, original emphasis)

Texts (whether they be written, read, spoken, or enacted as movements) create - draw - space by those who write, speak and move in them. For postcolonial diasporas everyday life has its own set of 'oppressions of the present' (de Certeau, 1984); and of the past for that matter. In contradistinction to the rigours of linguistic, semiotic and hermeneutic methods for analysing, interpreting the written word, de Certeau maintains that no 'text' can be adequately understood if isolated from the socio-historical context of its production and reception. In this sense 'any account is an account of a journey - a spatial practice’ (de Certeau 1984: 115 / 1980:206); a traversal in all 
senses of the term. This is an historically grounded approach to the study of Internet-induced forms of 'virtual' realities, or public-ness. For de Certeau,

\begin{abstract}
'space' is never ontologically given. It is discursively mapped and corporeally practised ... it is not a space until it is practised by peoples' active occupation, their movements through and around it. In this perspective there is nothing given about a 'field'. It must be worked, turned into a discrete social space, by embodied practices of interactive travel. (Clifford 1997, p. 54).
\end{abstract}

Providing ready-made and copious textual records and movements through cyberspace, internet discussions constitute (online archives of) practices of everyday life (online). Practices that 'poach' (de Certeau, 1980, p.10) from available ICT configurations for as long as is feasible or desirable. Like people moving through the physical spaces of cities, homes, and shopping malls on the ground, these practitioners leave palpable, electronic and textual traces of comings and goings online; written texts, and electronic traces that have something to say and in so doing, create (cyber)space. In this sense, Internet technologies can enable, facilitate the creation of more accessible, more permeable spaces for these participants to talk about and re-enact challenges to all sorts of situations and concerns on the ground, and online as these arise. That said, time needs to be taken to see how 'practised places' online unfurl (de Certeau, 1984, p. 130) and interpret what they might mean, figuratively and literally. For people's 'active occupation, their movements through and around' these spaces (Clifford, 1997, p. 54) entail both confidentiality - intimate exchanges - and declamatory positionings designed for a wider audience; texts that are hyperlinked to one another, readable and printable for anyone who takes the time. This is where oral communicative cultures (see Friedman 1998) meet the polyphonic, lateral qualities of online textual practices. Pacific Island communicative cultures - as oral recitations, bodily engravings, song and cumulative narratives - recognise de Certeau's critical point to western audiences as a matter of course (Wendt, 1999, p. 402; Smith $1999 ;$ p.50). The interactive, lateral and intertextual qualities of web textualspatial practices (hyperlinking being the key facilitator here) upset not only the rule of the authorial, linear narrative of western knowledge production but they also underscore the temporality of its own narrative. As such, these online practices, and the cyberspaces they open up, populate and cultivate, 
are but some examples of internet-enabled places where

ethnic and racial identity are examined, worked through, and reinforced. Cyberspace can provide a power coalition building and progressive medium for 'minorities' separated from each other by distance and other factors. On the other hand, these nodes of race in cyberspace are marked as being parts of the whole, islands of otherness in a largely white, male, and middle-class cyberspace. (Kolko, Nakamura and Rodman, 2000, p. 9)

As socially 'co-constructed' (Harding, 1998) ICTs need to be regarded as more than exogenous forces impacting on society in a unidirectional way (whether that be considered desirable or not). That said, how do these online practices relate to Pacific Island communities, as diasporas and island societies on the ground. How does their study enrich current understandings of translocality, diasporic or postcolonial everydayness that unfold in the west, between and within Pacific Island societies?

\section{Postcolonial travels}

I follow Albert Wendt's cue when he stipulates that the 'post in postcolonial does not just mean after; it also means around, through, out of, alongside, and against' (in Wilson, 1999, p. 3, original emphasis; Wendt, 1999; Seth, 1999, pp. 215-218). More to the point in historical and political terms is the struggle over whose memories, which narratives are favoured in a time that Wilson characterises as a 'mixed-up era of technoeuphoric globalisation and heightened localisation and reindigenisation' (1999, p. 2, see Smith 1999). James Clifford locates these conceptual and historical conjunctures well when he points out that contemporary

articulations of 'diaspora' .... [are] ways of sustaining connections with more than one place while practising non-absolutist forms of citizenship......The diasporic and hybrid identities produced ... can be both restrictive and liberating. They stitch together languages, traditions, and places in coercive and creative ways, articulating embattled homelands, powers of memory, styles of transgression, in ambiguous relation to national and transnational structures. It is difficult to evaluate, even to perceive, the range of emerging practices. (Clifford, 1997, pp. 9-10) 
Many of the sharpest, longest and most recurring $\mathrm{KR}$ and $\mathrm{KB}$ discussions, on personal or cultural identity, Pacific Island politics (those in Tonga especially - see Franklin, 2004, p. 106 passim), sex-gender roles, race/ethnicity, cultural 'survival', religion and morality pivot on these articulations, contestations of silences in official narratives, at home and abroad. The online practices of Pacific Island (Tongan, Samoan and other) postcolonial diasporas underscores the translocal (Clifford, op. cit.) dimensions to their everyday lives on the ground as well as the enabling characteristics of internet technologies to permit these sorts of translocal commutations. Postcolonial societies and/or their diasporas live in situations that are 'travelling' rather than fixed in time or space (Clifford 1997, p. 244) as a matter of course; emerging as multiple renderings of gender, race and class; of what 'being Tongan', 'being a Samoan woman today' actually involves; coming up with more positive, inclusive visions of the future for 'Polys' or PI communities wherever they are.

\section{In conclusion: Keeping cyberspace open}

To recall, diasporic Pacific Island communities are clustered in urban centres in the West. In the islands, internet access is, unsurprisingly, also based in urban centres (Apia, Honolulu, Suva, Nuku'alofa). For first and second generations growing up elsewhere, these cyberspatial practices trace shifts - both liberating and frustrating - in personal, family, social and cultural relationships. But, as is the case all too often in on-the-ground accounts of both technological successes or failures, those who have been absented from official accounts have actually always been 'there', offline as well as online. Whilst negotiating their everyday lives on the ground as a 'minority of a minority' (Aiono, 1999, interview) in Western societies, KB'ers and KR patrons have been populating and creating public cyberspace as they traverse the WorldWide Web. Doing so on their own terms, renegotiating expectations from family and communities closer to home or 'back home in the islands'; all of which indicate a variety of personal, group or community pressure points that need, and elicit a range of responses. The intimate details, politicised interventions are embedded in the characteristics of online-ness as well as the way these forums are run. Far from showing a passive consumption of a predetermined technology (de Certeau, 1980, pp. 11-14), or 'just' providing mutual support networks, ${ }^{10}$ these online traversals need to be grasped as part of 
the (post)colonial historical context of the South Pacific Islands themselves. Diasporic traversals of the World-Wide Web's remaining public spaces that express everyday embodiments, socio-economic impediments, intra and intercultural crunches, and visions of the future.

It would be tempting to draw definitive conclusions about whether the $\mathrm{KB}$ and $\mathrm{KR}$ forums, and related website clusters are, indeed, models for a 'new public sphere' (Kellner, op. cit.), whether that be indigenous, diasporic or a combination of these two locations and translocalities in ostensibly multicultural and/or postcolonial societies. This I won't do as a lot more indepth, longitudinal, and comparative research (online and also at the intersection of online and offline realms) needs to be done. This, and other studies, are just a start. I will say this much, though: commercialised browser and hypertext functionalities (the all-conquering commercial success of the Google Search Engine as the current case in point) along with the continued concentration of power to decide the technical and social way ahead for ICTs in the hands of fewer and large mega-media conglomerates, has nothing to do with public-ness or openness in the socio-economically equitable, accessible and inclusive sense of the word. ICTs and their co-requisite 'information societies' are not born; they are made. In terms of whether 'this' internet provides a 'public sphere' in and of itself begs questions about to what uses these malleable, and also inert, constellations of software and hardware architectures are being put; by and for whom. The Pacific Islands Online, as created and maintained by the Kava Bowl, Kamehameha Roundtable and like-minded sistah/bruddah sites in their footsteps, ${ }^{11}$ need to be grasped as part of the contemporary Pacific Islands on the ground; a site that is openly practised, for better or worse, as a 'global' and an ICT-indebted one. Closer study of cyberspatial practices such as these are indispensable to figuring out what equitable internet-mediated futures for the Pacific Islands - Pacific internet/s - might actually entail. Content-wise, as living archives, they offer observers (and participants) an invaluable insight into the issues and concerns that really rile or inspire younger generations of the postcolonial Pacific. These populations, as they navigate their way through, to and from these pioneering portals have been steadily, and modestly (re)creating open and inclusive cyberspaces from the ground up. 


\section{Notes}

${ }^{1}$ These two quotes are taken from the Kava Bowl (KB, 1995-2001) and Kamehameha Roundtable (KR, 1996 - present day) Internet Discussion Forums. All citations from here on in are quoted verbatim. More details are in the Bibliography under the name of the writer, date and title of the initial post (the first message posted) to which responses - follow-ups - are posted on the forum. Follow-ups form into discussion threads of varying length. Participants sign off in various ways - their real or pen-names which are linked to their email address (functional or fictional). See Franklin (2004, p. 168 passim) for the rationale behind this sort of referencing; Morton (2001) for more on nicknames and how (quasi-) anonymity operates in the Kava Bowl; Jones (1999) and Kolko, Nakamura and Rodman (2000) for more on internet research methods and ethics in general. See http:Polycafe.com for the user interface and other visuals.

${ }^{2}$ This article draws on Franklin (2004). See also Franklin (2001, 2002, 2003), Lee (2003), Ogden (1999).

${ }^{3}$ This was an early Tongan website set up by the Kava Bowl founder, Taholo Kami (www. tongaonline.com)

${ }^{4}$ Ascertaining participation levels (and significance accordingly) depends on the parameters that are set. If by email listserv lists then the total is in the hundreds; by the number of 'hits' a website gets, then thousands to tens of thousands; Planet Tonga gives an ongoing update in its registered users and who is online at any time in its live - real-time forums. See Franklin (2004, pp.6-9, 206-211).

${ }^{5}$ By diaspora I am referring to geographically dispersed populations that left the Pacific Islands in the 1960s and 1970s. More on this later.

${ }^{6}$ In Polynesian public communicative cultures women are to be seen and not heard. For instance the faikava ceremony on which the internet Kava Bowl is based is a male-dominated activity. Women are usually only there to serve and make the kava, namely in their ceremonial role (tou'a). Internet-based communications have allowed women and other silenced groups (political dissidents, homosexuals) a space in which to speak.

${ }^{7}$ The inner and external dynamics of these discussions, both in their form and content, are spliced with the geo-historical specifics of various Pacific Island migrations in the 1960s and 1970s, and, since then, the large numbers of younger generations who have been furthering their schooling overseas, in New Zealand. Australia and the US. These demographic and on-the-ground community/opportunity distinctions are grist to the mill in a Kava Bowl or Kamehameha Roundtable debate; between US-based Tongans and those living in Tonga; between American and Western Samoans, and also between these and New Zealand-based Pacific Island communities, which significantly outweigh those living elsewhere. See Lee (2003), Macpherson (1997), Macpherson, Spoonley, and Anae (2001), Wassmann (1998). 


\section{THE INDIGENOUS PUBLIC SPHERE}

${ }^{8}$ In Samoan, the term is afakasi. The English translation for this term, 'halfcaste', is also used. Fie palagi and faka palangi are somewhat pejorative terms in Samoan and Tongan respectively for those who are seen to be taking up Western/ European ways.

${ }^{9}$ In Tongan, the term is faka'apa'apa which is also a formal form of address to be found at the end of many messages.

${ }^{10}$ Over the years, many women and men have expressed their gratitude for this side to the forums.

${ }^{11}$ See Pacific Web Directory (www.pacificforum.com); Planet Tonga (www.planettonga.com); Samoalive (www.Samoalive.com); Samoan Sensation (www.samoa.co.uk); David Robie's Café Pacific (www.asiapac.org.fj/cafepacific/). And many more.

\section{Bibliography}

$\sim$ ALOJAH (2000, November 25). I dislike the term Polynesian, initial post. Kamehameha Roundtable Discussion Forum. Retrieved February 28, 2001: http:/ /polycafe.com/Kamehameha/kamehameha.htm

Aiono, A. (1999, July 15). Founder of the Polynesian Café. (Telephone interview, San Francisco - Los Angeles).

'Alopi Sione Latukefu (1996, September 23). Knowledge is Power! Power is Knowledge! Initial post in Kava Bowl Discussion Forum. Retrieved September 24, 1996: http://pacificforum.com

Ashcroft, B., Griffiths, G. and Tiffin, H. (1998). Key concepts in post-colonial studies. London/New York: Routledge

Benhabib, S. and Cornell, D. (Eds.) (1987). Feminism as critique. Cambridge: Polity Press.

Borradori, G. (2003). Philosophy in a time of terror: Dialogues with Jürgen Habermas and Jacques Derrida. Chicago/London: University of Chicago Press.

Chowdhry, G. and Nair, S. (Eds.) (2002). Power, postcolonialism and international relations: Reading race, gender and class. London/New York: Routledge

Clifford, J. (1997). Routes: Travel and translation in the late twentieth century. Massachusetts, London: Harvard University Press,

concerned (2000, January 13). Thank you Pua for enlightening me. And if you miss Pua's message, here it is again, initial post. Kamehameha Roundtable Discussion Forum. Retrieved February 1, 2000: http://polycafe.com/Kamehameha/ kamehameha.htm

Cyber-cop (1996, September 20). Anyone's site!, initial post. Kava Bowl Discussion Forum Retrieved September 24, 1996: http://pacificforum.com

Daily Planet (1999, November 22). NEW KID - WHO ARE YOU - WHERE DID YOU COME FROM - WHAT DO YOU WANT - WHERE DO YOU HOPE TO GO??????, initial post. Kamehameha Roundtable Discussion Forum. Retrieved January 19, 2000: http://polycafe.com/Kamehameha/kamehameha.htm 
de Certeau, M. (1980a). L'invention du quotidien: I Arts de faire. Paris: Union Générale d'Editions.

de Certeau, M. (1984). The practice of everyday life (translated by Steven Rendall). Berkeley, London: University of California Press.

Dyrkton, J. (1996). Cool runnings: The coming of cyberreality in Jamaica. In R. Shields (Ed.), Cultures of internet: Virtual spaces, real histories, living bodies (pp. 4957). London, Thousand Oaks/New Delhi: SAGE Publications.

eb (2001, March 12). Any future US political clout for PI's?? initial post in Kamehameha Roundtable Discussion Forum. Retrieved April 13, 2001: http:// polycafe.com/Kamehameha/kamehameha.htm

Franklin, M.I. (2001). InsideOut: Postcolonial Subjectivities and Everyday Life Online. International Feminist Journal of Politics, 3 (3): 387-422.

Franklin, M.I. (2002). Reading Walter Benjamin and Donna Haraway in the age of digital reproduction. Information, Communication and Society, 5(4): 591-624.

Franklin, M.I. (2003). I define my own identity: Pacific articulations of 'race' and 'culture' on the internet. Ethnicities, 3 (4): 465-490.

Franklin, M.I. (2004) Postcolonial politics, the internet and everyday life: Pacific traversals online. London/New York: Routledge.

Friedman, J. (1998). Knowing Oceania or Oceania knowing: Identifying actors and activating identities in turbulent times. In J. Wassmann (Ed.), Pacific answers to western hegemony: Cultural practices of identity construction (pp. 37-66). Oxford: Berg.

From a Concerned Hawaiian (2001, January 29). About Kamehameha..., initial post, Kamehameha Roundtable Discussion Forum. Retrieved February 28, 2001.

Habermas, J. (1989). The structural transformation of the public sphere. Cambridge UK: Polity Press, pp.231-5. In W. Outhwaite (Ed.), 1996, The Habermas reader (pp. 28-31). Cambridge UK: Polity Press.

Harding, S. (1998). Is science multicultural? Postcolonialisms, feminisms, and epistemologies. Bloomington and Indianapolis: Indiana University Press.

Henwood F., Hughes, G., Kennedy, H., Miller, N. and Wyatt, S. (2001). Cyborg lives in context: Writing women's technobiographies. In F. Henwood, H. Kennedy and N. Miller (Eds.), Cyborg lives: Women's technobiographies (pp. 11-34). York: Raw Nerve Books.

Hereniko V., and Wilson, B. (Eds.) (1999). Inside out: Literature, cultural politics, and identity in the new Pacific. Maryland/Oxford UK: Rowman \& Littlefield.

Highmore, B. (2002). Everyday life and cultural theory: An introduction. London, New York: Routledge.

Jones, S. (Ed.), (1999). Doing internet research: Critical issues and methods for examining the net. London, Thousand Oaks, New Delhi: SAGE Publications.

Jordan T. (1999). Cyberpower. London/New York: Routledge.

KB Admin (1998, September 14). Weekly Discussion Topic \# 52: Poly violence...heritage, or hate?, initial post in Kava Bowl Discussion Forum. Retrieved October 6, 1998: http://pacificforum.com 


\section{THE INDIGENOUS PUBLIC SPHERE}

KBAdmin (1998, March 9). Weekly Discussion Topic \#31: For the overseas Tongan, What does 'being' Tongan mean?, initial post in Kava Bowl Discussion Forum. Retrieved October 23, 1998: http://pacificforum.com

KB Admin (1998, November 16). Weekly Discussion Topic \#59: Living overseas... In a Poly community, or not?, initial post in Kava Bowl Discussion Forum. Retrieved November 16, 1998: http://pacificforum.com

Kellner, D. (1998). Intellectuals, the new public spheres, and techno-politic. In C. Toulouse and T.W. Luke (Eds.), The politics of cyberspace (pp. 167-186). New York and London: Routledge.

Kolko B. E, Nakamura L., and Rodman G. B. (Eds.) (2000). Race in cyberspace. New York and London: Routledge.

KZ7 (2000, March 28). Where are the caring women?, initial post in Kamehameha Roundtable Discussion Forum. Retrieved May 19, 2000: http://polycafe.com/ kamehameha/kamehameha.htm

Lafemme N. (1999, May 19). I'm tired of slaving myself - the role of the woman, initial post in Kava Bowl Discussion Forum. Retrieved January 31, 2001: http:// pacificforum.com; initial post in Polycafe. Retrieved May 21, 1999: http:// Polycafe.com

Lafemme N. (1999, April 23). The right to freedom of speech, initial post, Kamehameha Roundtable Discussion Forum. Retrieved June 8, 1999: http://polycafe.com/ Kamehameha/kamehameha.htm

Lausii (1999, May 18). WOMEN'S RIGHT, initial post in Kava Bowl Discussion Forum. Retrieved January 31, 2001: http://pacificforum.com

Lee, H. (2003). Tongans overseas. Honolulu: Hawaii University Press.

Loader B. (Ed.), (1998). Cyberspace divide: Equality, agency and policy in the information society. London/New York: Routledge.

Ludlow, P. (Ed.), (1996). High noon on the electronic frontier: Conceptual issues in cyberspace. Boston MA: MIT Press.

Macpherson, C. (1997). The Polynesian diaspora: New communities and new questions. In K. Sudo and S. Yoshida (Eds.), Contemporary migration in Oceania: Diaspora and network (pp 77-100). Osaka: National Museum of Ethnology.

Macpherson, C., P. Spoonley and M. Anae (Eds.), (2001). Tangata O Te Moana Nui: The evolving identities of Pacific peoples in Aotearoa/New Zealand. Palmerston North: Dunmore Press.

Mansell R. and Silverstone R. (Eds.), (1996). Communication by design: The politics of information and communication technologies. Oxford: Oxford University Press.

Mansell R. and Wehn U. (1998). Knowledge societies: Information technology for sustainable development. United Nations/Oxford: Oxford University Press.

May, C. (2002). The information society: A sceptical view. Cambridge/Oxford: Polity Press.

McChesney R., Wood E., Foster, J. (Eds.), (1998). Capitalism and the information age: The political economy of the global communication revolution. New York: Monthly Review Press.

McNicholas, P., Humphries, M. and Gallhofer, S. (2003). Maintaining the empire: 
Maori women's experiences in the accountancy profession. In Critical Perspectives On Accounting Journal, 1044: 1 - 37

Meilakepa, (2005, March 20). Thank you Al and Sue, initial post in Kamehameha Roundtable Discussion Forum. Retrieved March 31, 2005: http://polycafe.com/ Kamehameha/kamehameha.htm

Miller D. and Slater, D. (2000). The internet: An ethnographic approach. Oxford: Berg. Available online at http://ethnonet.gold.ac.uk/summary.html

Mitra, A. and Cohen, E. (1999). Analyzing the web: Directions and challenges. In S. Jones (ed), Doing internet research: Critical issues and methods for examining the net (pp. 179-202). London, Thousand Oaks, New Delhi: SAGE Publications.

Moore-Gilbert B., Stanton G. and Maley W. (Eds.), (199). Postcolonial criticism, London: Longman.

Morton, H. (2001). I is for identity: What's in a name? In H. Morton (Ed), Computermediated communication in Australian anthropology and sociology, Special Issue of Social Analysis: Journal of Cultural and Social Practice, 45 (1): 67-80

Morton, H. (1999). Islanders in space: Tongans online. In R. King and J. Connell (Eds.), Small worlds, global lives: Islands and migration (pp. 235-254), London and New York: Pinter.

Mr.Mrs 1st generation lost, 31/12/04, The Value Of Remembering Samoan Culture, initial post, Kamehameha Roundtable Discussion Forum, http://polycafe.com/ Kamehameha/kamehameha.htm, accessed 31/03/2005

MVP (1999, November 13). DOES THE FAKA-PALANGI ATTITUDE DESERVE TO BE CRITICISED? initial post in Kava Bowl Discussion Forum. Retrieved November 15, 1999: http://pacificforum.com

OECD (2001). Understanding the digital divide. Paris: OECD.

Ogden, M. R. (1999). Islands on the internet. In Pacific Telecommunications Review, 21(2): 5-16.

Ortner, S. B. (1996). Making gender: The politics and erotics of culture. Boston: Beacon Press.

Peterson, V. S. (2003). A critical rewriting of global political economy: Integrating reproductive, productive and virtual economies. London/New York: Routledge.

POLYCAFE (1999, May 4). ALL SUBJECT HEADINGS LONGER THAN 1 LINE WILL BE DELETED!, initial post in Polycafe. Retrieved May 21, 1999: http://polycafe.com Rubin, G. (1997/1975). The traffic in women: Notes on the 'political economy' of sex. In L. Nicholson (Ed.), The second wave: A reader in feminist theory (pp. 27-62). New York/London: Routledge.

Sam Owens (1999, May 20). Thank you Polycafe for doing away with posts with slang and profanity!!!, initial post in Polynesian Cafe, Retrieved May 21, 1999: http://polycafe.com

Sandy Macintosh (2000, March 27). RE: Kava Bowl, initial post in Kava Bowl Discussion Forum. Retrieved May 19, 2000: http://pacificforum.com

Schiller D. (1999). Digital capitalism: Networking the Global market system. Cambridge MA: MIT Press.

Seth, S. (1999). A 'postcolonial world?' in G. Fry and J. O’Hagan (Eds.), Contending 


\section{THE INDIGENOUS PUBLIC SPHERE}

images of world politics (pp. 214-266). Houndmills, Basingstoke, Hampshire: Macmillan.

Sharf, B. F. (1999). Beyond netiquette: The ethics of doing naturalistic discourse research on the internet. In S. Jones (Ed.), Doing internet research: Critical issues and methods for examining the net (pp. 243-256). London, Thousand Oaks, New Delhi: SAGE Publications.

Shields R. (Ed) (1996). Cultures of internet: Virtual spaces, real histories, living bodies. London, Thousand Oaks, New Delhi: SAGE Publications.

Smith, L. T. (1999). Decolonising methodologies: Research and indigenous peoples. London: Zed Books.

taeoli (2000, February 4). KB ADMINISTRATION? WHAT'S THE FUNDAMENTAL PRINCIPLE?, initial post in Kava Bowl Discussion Forum Retrieved January 28, 2000: http://pacificforum.com

Thoughts (1999, May 22). How to tell if you are Samoan, initial post in Kamehameha Roundtable Discussion Forum. Retrieved May 22, 1999: http://polycafe.com/ kamehameha/kamehameha.htm

TonganRasta (2001, June 6). Samoan/Tongan conflict, initial post in Kamehameha Roundtable Discussion Forum. Retrieved June 7, 2001: http://polycafe.com/ Kamehameha/kamehameha.htm

Toulouse, C. and Luke, T. W. (Eds.) (1998). The politics of cyberspace. New York and London: Routledge.

Wassmann, J. (Ed.) (1998). Pacific answers to western hegemony: Cultural practices of identity construction. Oxford: Berg.

Wendt, A. (1999). Afterword: Tatauing the post-colonial body. In V. Hereniko and R. Wilson (Eds.), Inside out: Literature, cultural politics, and identity in the new Pacific (pp. 399-412). Maryland/Oxford UK: Rowman \& Littlefield.

Wilhelm, A. G. (2000). Democracy in the digital age: Challenges to political life in cyberspace. New York/London: Routledge.

Wilson, R. (1999). Introduction: Toward imagining a new Pacific. In V. Hereniko and R. Wilson (Eds.), Inside out: Literature, cultural politics, and identity in the new Pacific (p. 1-16). Maryland/Oxford, UK: Rowman and Littlefield.

WIRED Magazine (1998a, November). The wired world atlas, p.162.

WIRED Magazine (1998b, November). Updata: '.tvland', p.104.

Wyatt S., Thomas G. and Terranova T. (2002). 'They came, they surfed, they went back to the beach': Conceptualising use and non-use of the internet" in S. Woolgar (Ed), Virtual society? Technology, cyberpole, reality (pp. 23-40). Oxford: Oxford University Press. 
THE INDIGENOUS PUBLIC SPHERE Dr Marianne Franklin is assistant professor in social and political theory at the University for Humanist Studies, Utrecht, The Netherlands, and teaches international relations and social sciences in the masters programmes of the University of Amsterdam's International School for the Humanities and Social Sciences (ISHSS).

M.I.Franklin@uvh.nl

www.uvh.nl

Pacific

Journalism Review

Pacific Journalism Review back copies

Back copies of Pacific Journalism Review can be ordered from:

South Pacific Books NZ Ltd www.southpacificbooks.co.nz USP Book Centre www.uspbookcentre.com

PJR subscription details and order forms are online at: www.pjreview.info 
Copyright of Pacific Journalism Review is the property of Auckland University of Technology and its content may not be copied or emailed to multiple sites or posted to a listserv without the copyright holder's express written permission. However, users may print, download, or email articles for individual use.

http://Mww.aut.ac.nz/depts/commstud/journ/pjrsubs.shtml 